\title{
Acción antimicrobiana in vitro de dentífricos conteniendo fitoterápicos
}

\author{
Liza Barreto $V^{*}, M^{a}$ do Socorro Costa Feitosa $A^{* *}$, Joás de Araújo T***, \\ Karine Chagas $\mathrm{F}^{* * * * *}$, Kenio Costa L*****
}

\section{RESUMEN}

Éste estudio analizó el potencial antimicrobiano in vitro de 7 dentífricos conteniendo fitoterápicos sobre bacterias orales recuperadas de la saliva y cepas patrón de S. mutans ATCC25175, S. sanguis ATCC 10556 y L. casei ATCC 4646. Fueron obtenidas soluciones concentradas de los dentífricos evaluados y de controles mezclándose 3 gramos de cada uno con $10 \mathrm{~mL}$ de agua deionozada estéril, seguido de centrifugación; los sobrenadantes resultantes fueron diluidos en proporciones de 1:2 hasta 1:32. Fue realizado un test de difusión en ágar, colocando cepas patrón y la saliva total estimulada de 10 pacientes saludables. Discos empapados con las suspensiones de los dentífricos fueron dispuestos en las placas, las cuales fueron incubadas en anaerobiosis por 48 horas, siendo los aros de inhibición medidos en milímetros. Los resultados obtenidos fueron analizados mediante ANOVA y llevando en consideración el control positivo se constató que, solamente las soluciones puras de los dentífricos presentaron capacidad antimicrobiana contra cepas patrón, equivalente a la del dentífrico con triclosan, excepto el Gessy Cristal ${ }^{\circledR}$. Además, los dentífricos diluidos a 1:2 presentaron acción antimicrobiana contra las bacterias orales recuperadas de la saliva, excepto el Parodontax ${ }^{\circledast}$.

Palabras clave: dentífricos; fitoterápicos; acción antimicrobiana.

\section{SUMMARY}

The aim of this study was to evaluate and compare in vitro antimicrobial potential of 7 dentifrices containing phytotherapics agents oral bacteria obtained from saliva and standard strains of S. mutans ATCC 25175, S. sanguis ATCC 10556, and $L$. casei ATCC 4646. For this purpose, concentrated test and control solutions were obtained by mixing 3 grams of each in $10 \mathrm{ml}$ of sterile deionized water which was submitted to centrifugation, the sublimate obtained was further dissolved in a ratio of 1:2 to 1:32. A diffusion test in agar was carried out by sowing the standard strain and stimulated total saliva. Disks soaked in a dentifrices solution and then placed on culture disks were then incubated in anarobiosis for 48 hours. Inhibition halos were then measured. Results obtained from ANOVA statistical analysis. However, comparison in the presence of a positive control, revealed that against standard strains, the pure solution of the dentifrices had antimicrobial activity, with the exception of Gessy Cristal ${ }^{\oplus}$. Against oral bacteria recovered from saliva, diluted dentifrices to 1:2 showed the same activity, excepting Parodontax ${ }^{\circledR}$

Key words: dentifrices; antimicrobial activity; phytotherapics.

Aceptado para publicación: Octubre 2004.

* Estudiante del Programa de Pós-graduación en Odontologia Preventiva y Social (Universidad Federal de Rio Grande del Norte).

** Doctor en Odontolgia Preventiva y Social (Universidad Federal de Pernambuco) y profesor del Programa de Pós-graduación en Odontologia Preventiva y Social (Universidad Federal de Rio Grande del Norte).

*** Mestre en Odontologia Preventiva y Social (Universidad Federal de Rio Grande del Norte)

**** Cirurgia-dentista ((Universidad Federal de Rio Grande del Norte).

***** Doctor en Microbiologia (Universidad Federal de Rio del Janeiro) y profesor del Programa de Pós-graduación en Odontologia Preventiva y Social (Universidad Federal de Rio Grande del Norte).

Liza Barreto V, Ma do Socorro Costa Feitosa A, Joás de Araújo T, Karine Chagas F, Kenio Costa L. Acción antimicrobiana in vitro de dentífricos conteniendo fitoterápicos. Av. Odontoestomatol 2005; 21-4: 195-201. 


\section{INTRODUCCIÓN}

La fitoterapia, palabra derivada del griego, phyton (planta) y therapia (tratamiento) es luna práctica usada desde la antigüedad. El primer manuscrito conocido al respecto de ésta práctica es el Papiro de Ebers, de 1500 a. C., descubierto por el egiptólogo alemán Georg Ebers en 1827. Actualmente, las investigaciones realizadas con hierbas, generalmente confirman los usos tradicionales de las plantas, ofreciendo a los investigadores la convicción de que hay mucho que aprender con las costumbres populares. Un análisis científico de las especies de uso popular propició que la fitoterapia se aproximara de la Aloterapia, de tal forma que actualmente $80 \%$ de la medicación vendida en Alemania es elaborada con fitoterápicos. Sin embargo, a pesar de que algunas hierbas ya son bien conocidas, de otras no se sabe ni su composición. Apenas entre 300 y 400 plantas son estudiadas en el mundo y solo el Brasil posee mas de 100 mil especies vegetales, de las cuales menos de $1 \%$ fueron estudiadas científicamente $(1,2)$.

Recientemente, extractos de plantas han sido incorporados a las fórmulas de los dentífricos, que además de desempeñar funciones cosméticas, tienen el objetivo principal de mejorar la acción antimicrobiana y actuar como agentes terapéuticos. La acción terapéutica de los dentífricos no está relacionada únicamente a la presencia del flúor en su composición, visando la prevención y ó la reversión de lesiones de caries incipientes, sino que también otras substancias están siendo incorporadas a las fórmulas (3).

Basados en lo antes citado, extractos de plantas como la sálvia, menta y camomila (manzanilla) han sido incorporados a las fórmulas dentífricas con el intuito de reducir la halitosis y combatir la gingivitis $(1,2)$. De tal forma, los principios activos de esos fitoterapicos actuarían sobre una masa de bacterias extremamente organizadas que se adhieren selectivamente a las superficies dentales y constituyen el biofilm dentario.

Entre los agentes fitoterápicos incorporados a los dentífricos se destaca el Aloe vera, también conocido como sábila, que es una planta de la familia de las liliáceas, originaria de regiones tropicales calientes y semi áridas, especialmente del África. Es llamada la "planta de la salud y la belleza", utilizada desde la época del antiguo Egipto. Actualmente, diversas instituciones científicas estudian ésta planta y relatan, entre otras propiedades, derivadas de sus principios activos, la acción antinflamatoria y antibiótica. El Aloe vera contiene más de 75 componentes divididos en varios grupos, entre los cuales pueden ser citados las vitaminas, sales minerales, aminoácidos y saponinas. Su acción se caracteriza por la disponibilización de diversos elementos nutricionales que actúan cinérgicamente en los tejidos epiteliales y en el sistema inmunológico donde, por su acción antinflamatoria y antimicrobiana, induce el crecimiento celular, favoreciendo la recuperación del tejido agredido. El Aloe vera es rico en aloeferon, antraquinona y acemannan. El aloeferon actúa en la multiplicación celular, acelerando la cicatrización; la antraquinona es un antiséptico. El acemannan es un mucopolisacarídeo con acción antiviral, antibacteriana y antimicótica, actúa sobre las células del sistema inmunológico activando y estimulando macrófagos monócitos, linfócitos y anticuerpos $(4,5,6,7)$.

Otro fitoterapico incorporado a los dentífricos es el extracto de "juá", obtenido a partir de la raspa de la cáscara del "joazeiro" (Ziziphus joazeiro mart), árbol típico de la región nordeste del Brasil. La raspa del "juá" viene siendo usada desde hace muchos años como dentífrico, basado apenas en costumbres populares. La cáscara del "juazeiro" es rica en saponina, un complejo molecular de la familia de los glucósidos, lo que le confiere propiedades detergentes. Además de la acción detergente ó tenso activa el "juá" presenta también propiedad abrasiva, sin embargo no es capaz de producir desmineralización del esmalte dental (8). El principal constituyente químico del "juá" es una saponina triterpénica derivada del ácido oleanólico. El juá es usado en forma de polvo ó de raspa como agente de higiene oral. El polvo es obtenido a partir de la entrecorteza seca, debiendo ser cernido y guardado en frascos herméticamente cerrados. Como agente anti caries, tal polvo es considerado más eficiente que los dentífricos comunes en la retirada del biofilm microbiano dental a través del cepillado, siendo usado en cantidad que se prenda al cepillo húmedo (9). 
Cada vez mas, numerosos productos con ingredientes de origen vegetal están siendo ofrecidos, los cuales ejercen una influencia inhibidora en el crecimiento del biofilm dental de la cavidad bucal. Estudios in vitro han mostrado que tinturas de camomila (Matricaria chamomilla L.) y mirra poseen efecto sobre ciertos microorganismos formadores de biofilm comparable al de la clorexidina (10).

Extractos de plantas, tales como la equinácea, ratánea y salvia son también usados debido a que proporcionan una eficacia antinflamatoria y antiséptica (10).

La camomila tiene acción cicatrizante, antiséptica y antinflamatoria, combatiendo la estomatitis, infecciones bucales y aftas. La salvia (Salvia officinalis L.) posee acción antiséptica pudiendo ser usada en productos de higiene bucal, auxiliando en el tratamiento de afecciones orales (estomatitis, gingivitis, glositis, halitosis y aftas) (11).

Otras plantas tales como la menta pimienta (Menta peperita $L$.) contiene principalmente en sus hojas un aceite esencial rico en mentol, menonita y mentofurano, que posee propiedades antiespasmódica, antinflamatoria, anti úlcera y antiviral, usado en el combate de las estomatitis, halitosis e inflamaciones bucales. El eucalipto (Eucalipto globulus Labill) contiene 3 a $5 \%$ de aceite esencial, con $60 \%$ ó más de cíñelo ó eucaliptol, principal responsable por su actividad antigripal, balsámica y adstringente, siendo utilizado en el combate de la gingivitis $(7,12)$.

Un estudio in vitro evaluó la capacidad de inhibición sobre microorganismos cariogénicos, de 25 dentífricos comercializados en Brasil. Fue observado que de diluciones 1:2 hasta 1:64 de esos dentífricos, la crema dental Sorriso Ação Total ${ }^{\circledR}$ obtuvo una capacidad inhibidora mínima más eficiente sobre $S$. mutans, S. sobrinus y $L$. casei, por otro lado, la que presentó la más alta acción antimicrobiana sobre $S$. mutans fue Sorriso Total ${ }^{\circledast}$; la crema Colgate Total ${ }^{\circledR}$ sobre S. sobrinus y finalmente la Signal Global ${ }^{\oplus}$ sobre $L$. casei, mostrando que los dentífricos conteniendo triclosan siempre presentan potencial antimicrobiano (13).

En un estudio realizado en la Clínica de Bebes de la
Disciplina de Odontopediatria de la facultad de Odontología de la Universidad de Río de Janeiro fueron seleccionados 40 bebes, de los cuales se colectaron saliva no estimulada y el biofilm dental, siendo evaluados los efectos de soluciones de dentífricos concentrados y diluidos (1:2 hasta 1:128) utilizados en el higiene oral de bebes, verificándose que la saliva y el agua deionizada (soluciones de control), las soluciones de bicarbonato de sodio e infusión de Matricaria chamomilla, así como los dentífricos conteniendo xilitol, lactoperoxidase, glicoseoxidase y lactoferrina combinados a extractos de Calendula officinallis no presentan cualquier efecto antimicrobiano, independientemente de la concentración y de la metodología utilizada (14).

Un estudio in vitro sobre la actividad antimicrobiana de las tinturas de malva, salva, camomila, tomillo, cacao y própolis contra $S$. mutans y $S$. sobrinus concluyó que la malva, salva y camomila no presentan acción inhibidora de la proliferación bacteriana (15).

A respecto de los agentes antimicrobianos incorporados a las fórmulas de dentífricos, podemos citar el triclosan (2,4,4,tricloro-2-hidroxidifenil éter) que presenta amplio espectro y está siendo utilizado desde hace 25 años en productos dermatológicos, jabones, desodorantes y recientemente, con suceso en los dentífricos, auxiliando en la remoción del biofilm dental. El triclosan posee fuerte actividad sobre bacterias y hongos orales, su primer sitio de actividad antimicrobiana es la membrana plasmática de los microorganismos y por sus características no iónicas, es bastante compatible con los abrasivos y fluoretos encontrados en los dentífricos. En bajas concentraciones, el triclosan interfiere en la absorción de los nutrientes, determinando un efecto becteriostático. En altas concentraciones es bactericida, determinando la ruptura de la membrana, llevando a derrame de los componentes celulares y consecuentemente, a la muerte celular. Sus efectos sistémicos son prácticamente inexistentes. También presenta buena retentividad en la mucosa oral, siendo de difícil remoción por los fluidos orales (13).

Debido a la existencia de pocos datos que comprueben la acción antibacteriana de fitoterápicos sobre las bacterias orales, el objetivo de éste estudio fue evaluar y comparar la acción antimicrobiana in vitro 
de siete dentífricos conteniendo fitoterápicos en su composición, disponibles en el mercado brasileño, sobre cepas patrón de S. mutans ATCC 25175, S. sanguis ATCC 10556, L. casei ATCC 4646 y sobre bacterias orales recuperadas de la saliva a través del test de difusión en agra. Además se verificó si las diluciones seriadas de los dentífricos evaluados presentan capacidad antimicrobiana y se comparó la acción antimicrobiana de éstos dentífricos con relación a uno conteniendo triclosan.

\section{MATERIAL Y MÉTODOS}

\section{- COLECTA DE LA SALIVA}

La saliva estimulada mediante la masticación de goma base, fue colectada de 5 pacientes con el propósito de evaluar los efectos de los dentífricos sobre la microbiota salivar. Cada paciente masticó goma base por un minuto, seguidamente desecho la saliva producida en ese tiempo y continuó masticándola por lo menos durante 5 minutos, depositando toda la saliva en recipientes estériles apropiados.

\section{- SELECCIÓN Y PREPARACIÓN DE SOBRENADANTES DE LOS DENTÍFRICOS}

Los dentífricos conteniendo fitoterápicos utilizados en el estudio fueron:

- Colgate Herba ${ }^{1 \circledast}$ (conteniendo mirra, salvia, camomila, eucalipto y 1500 ppm de flúor);

- Forever Bright ${ }^{1 \circledast}$ (conteniendo Aloe Vera, própolis y sin flúor);

- Gessy Cristal ${ }^{1}$ (conteniedo extrato de "juá")

- Parodontax ${ }^{1}$ (conteniendo equinácea, camomila, salvia, mirra, ratánia, bicarbonato de sódio y sin flúor);

- Sorriso Herbal ${ }^{1}$ (conteniendo camomila, eucalipto y 1500 ppm de flúor);

- Sorriso Herbal con Cálcio ${ }^{\circledR}$ (conteniendo hierba dulce, camomila, menta y 1500 ppm de flúor);

- Sorriso Herbal con Própolis ${ }^{\circledR}$ (conteniendo própolis y 1500 ppm de flúor).

Los dentífricos utilizados como control positivo y negativo respectivamente fueron:
- Sorriso Ação Total ${ }^{\circledast}$ (conteniendo triclosan, xilitol y 1500 ppm de flúor) - Debido a la acción antimicrobiana del triclosan éste dentífrico fue utilizado como control positivo;

- Phillips ${ }^{\circledast}$ (sin flúor).

La preparación de los sobrenadantes de cada dentífrico fue realizada debido a que los componentes solubles en agua de los dentífricos son los responsables por la acción antimicrobiana de los mismos. Basados en eso, primero fueron obtenidas soluciones concentradas de los dentífricos mezclandose por agitación durante un minuto en vibrador "vortex" 3 gramos de cada uno con $10 \mathrm{~mL}$ de agua deionizada estéril. Las suspensiones resultantes fueron centrifugadas durante 10 minutos a 500 rpm, con el objetivo de precipitar las partículas sólidas de los dentífricos. Los sobrenadantes resultantes fueron diluidos con agua deionizada estéril con la finalidad de obtener diluciones de 1/2,1/4,1/8,1/16 y 1/32 (14).

\section{- TEST DE DIFUSIÓN EN ÁGAR PARA LA VERIFICACIÓN DE LA ACCIÓN ANTIMICROBIANA DE LOS DENTÍFRICOS EVALUADOS SOBRE CEPAS PATRÓN DE S. mutans ATCC 25175, S. sanguis ATCC 10556, L. casei ATCC 4646 Y SOBRE BACTERIAS ORALES RECUPERADAS DE LA SALIVA.}

Inicialmente, placas de Petri conteniendo $25 \mathrm{~mL}$ de medio BHI (Brain Heart Infusión) fueron incubadas "overnight" a $37^{\circ} \mathrm{C}$ para garantizar su esterilidad. Fueron utilizadas cepas de $S$. mutans, S. sanguis y $L$. casei cultivadas en caldo de $\mathrm{BHI}$ a $37^{\circ} \mathrm{C}$ "overnigth". Después de comprobada la esterilidad de los medios, la saliva de cada paciente y cada cepa patrón de las bacterias fueron colocadas en las placas con la ayuda de "swabs' estériles. Seguidamente, utilizando una micropipeta automática, discos de antibiograma estériles (con $6 \mathrm{~mm}$ de diámetro) fueron empapados con 10 microlitros de cada solución. Los discos fueron colocados en el medio de cultura con una pinza estéril, obedeciendo a una disposición que evitase la sobre posición de los aros de inhibición y las placas fueron adecuadamente identificada e incubadas en ambiente de anaerobiosis en jarra Gaspak a $37^{\circ} \mathrm{C}$ por 48 horas para posterior verificación de los aros de inhibición (en milímetros). Con la 
finalidad de reducir la variabilidad y conseguir resultados fidedignos, el estudio fue realizado triplicadamente en cada paciente. Por lo tanto, para cada solución y sus respectivas diluciones, el valor de los diámetros de los aros de inhibición fue dado por la media de culturas en ágar BHI.

\section{- ANÁLISIS ESTADÍSTICA}

Los datos obtenidos fueron analizados estadísticamente mediante el Análisis de Variancia y el Test de Tukey para un nivel de significancia de $5 \%$

\section{RESULTADOS Y DISCUSIÓN}

Los valores correspondientes a los aros de inhibición para los dentífricos evaluados tienen distribución normal, por eso, se usaron métodos parametricos ANOVA y Test de Tukey.

Con relación a las bacterias orales recuperadas de la saliva, se verificó que soluciones puras y las diluciones 1:2 de los dentífricos evaluados presentaron acción antimicrobiana con formación de aros de inhibición superiores a $8 \mathrm{~mm}$ (figura 1). Sin embrago, a través del análisis estadístico fue observada diferencia significativa $(p=0,0001)$, llevando a inferir que los dentífricos puros presentaron mejor desempeño antimicrobiano que el de las soluciones diluidas.

Las soluciones puras y las diluciones 1:2 de los dentífricos Sorriso Herbal ${ }^{\circledast}$, Sorriso Herbal com Cálcio ${ }^{\circledR}$

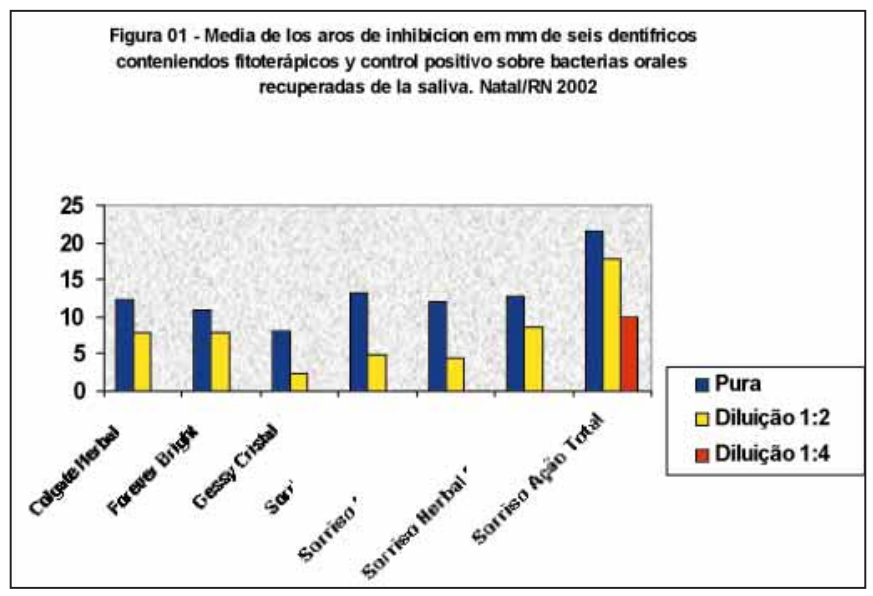

y Sorriso Herbal com Própolis ${ }^{\circledast}$ conteniendo camomila, presentaron capacidad antimicrobiana, divergiendo de Vieira (1999) quien observó que la infusión de Matricaria chamomilla no presentó ninguna actividad antimicrobiana independientemente de la concentración y de la metodología utilizada.

Por otro lado, cuando los dentífricos fueron comparados con el control positivo - Sorriso Ação Total ${ }^{\circledR}$ (solución pura y diluciones $1: 2$ y 1:4) - fue verificado que hubo diferencia estadísticamente significativa $(p=0,0001)$, concluyéndose que las soluciones puras y diluidas del dentífrico conteniendo triclosan presentaron acción antimicrobiana superior a la acción de las diluciones de los dentífricos evaluados. Sin embargo, las soluciones puras de otros dentífricos presentaron acción antimicrobiana similar al dentífrico control positivo.

De acuerdo con los resultados de éste estudio (figura 2), las soluciones puras y diluidas 1:2 de los dentífricos evaluados y la solución pura de la crema Gessy Cristal $^{\circledast}$ presentaron acción antimicrobiana sobre las cepas patrón. Para éstos dentífricos fueron observados aros de inhibición mayores que $8 \mathrm{~mm}$ para por lo menos una cepa después del tratamiento con las soluciones de los dentífricos referidos. Después del análisis de variancia, fue verificada una diferencia extremamente significativa $(p<0,0001)$, llevando a inferir que los dentífricos puros presentan mejor acción antimicrobiana que los diluidos.

Sin embargo, cuando los valores de los aros de inhibición observados en el tratamiento con el dentífrico control positivo - Sorriso Ação Total $^{\circledR}$ (solución pura

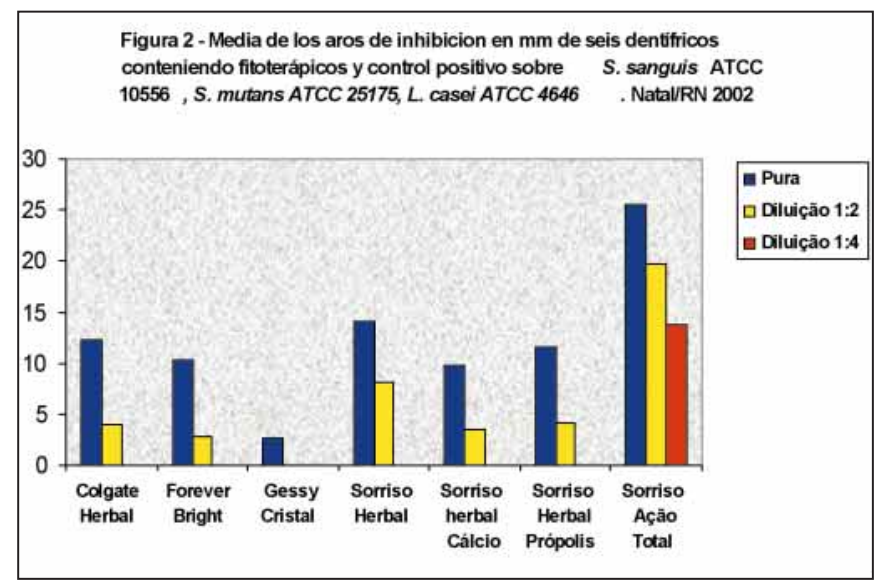


y diluciones 1:2 y 1:4) - sobre las cepas patrón fueron introducidos en el modelo estadístico, fue verificado que hubo diferencia estadísticamente significativa ( $<<0,0001$; intervalo de confianza 20,411 30,922; media y desvío patrón 25,66 \pm 6,837) entre éste dentífrico y las soluciones puras y diluciones 1:2 de los dentífricos evaluados con relación a la solución pura de la crema Gessy Cristal ${ }^{\circledR}$. Basados en esto, puede ser inferido que las soluciones pura y diluida 1:2 de los dentífricos presentaron acción antimicrobiana sobre las cepas patrón; sin embargo, solo la acción de sus soluciones puras son equiparables a la acción del dentífrico control positivo conteniendo triclosan. Por otro lado, la solución pura de la crema Gessy Cristal ${ }^{\circledast}$ presentó acción antimicrobiana sobre S. mutans, pero, su acción no fue superior a la del dentífrico Sorriso Ação Total ${ }^{\circledR}$.

Durante éste estudio fue verificado que el Parodontax ${ }^{\oplus}$ conteniendo equinácea, camomila, salvia, mirra y ratánea no presentó actividad antimicrobiana sobre las cepas patrón y sobre las bacterias orales recuperadas de la saliva. Éste hecho difiere del estudio de Velmovitsky et al. (2000) que observaron inhibición bacteriana en la concentración pura contra las bacterias $S$. mutans, S. sobrinus y $L$. casei. Según Pereira (1998), la mirra presente en la composición del Paradontax ${ }^{\circledast}$ posee acción antimicrobiana comparable a la clorexidina sobre algunos microorganismos formadores de biofilm dental. Sin embargo, corroborando lo observado por Gebara et al. (1996) las tinturas de camomila y salvia no presentaron inhibición de la proliferación bacteriana.

El dentífrico Sorriso Herbal ${ }^{\circledR}$ (conteniendo camomila y eucalipto), presentó actividad antimicrobiana en la concentración pura y la dilución 1:2 sobre por lo menos una de las cepas evaluadas. Según Velmovitsky et al. (2000), éste dentífrico puede presentar capacidad de inhibición bacteriana hasta la dilución 1:4. De acuerdo con Pereira (1998), la camomila contenida en el dentífrico Sorriso Herbal ${ }^{\circledR}$ tiene influencia sobre el biofilm dental. Matos (1998) afirma que el polvo del "juazeiro" es usado como anti caries, siendo considerado mas eficiente que los dentífricos comunes para la remoción del biofilm dental por medio del cepillado. En éste estudio fue observado que la solución pura de Gessy Cristal $^{\circledR}$ presentó acción antimicrobiana solo sobre $S$. mutans. Sin embargo, de acuerdo con Velmovitsky et al. (2000), éste dentífrico no presenta acción antimicrobiana, mostrando que el extracto de "juá" no tiene ningún poder inhibidor.

El dentífrico Phillips ${ }^{\circledast}$ (sin flúor) fue utilizado en éste estudio como control negativo y no presentó potencial de inhibición bacteriana, confirmando los datos de Velmovitsky et al. (2000). El dentífrico Sorriso Ação Total ${ }^{\circledast}$ (conteniendo triclosan), que fue utilizado como control positivo, presentó inhibición bacteriana hasta la dilución 1:4; sin embargo Velmovitsky et al. (2000), observaron una capacidad antimicrobiana hasta la dilución 1:16 sobre $S$. mutans y $L$. casei, además de acción antimicrobiana contra S. sobrinus hasta la dilución 1:8.

En conclusión, las soluciones puras y diluidas de los dentífricos evaluados presentaron acción antimicrobiana sobre las bacterias orales recuperadas de la saliva y sobre las cepas de $S$. sanguis, $S$. mutans y L. casei (ó por lo menos sobre una de éstas), excepto el dentífrico Gessy Cristal ${ }^{\circledast}$ que para éstas cepas presentó acción apenas en la solución pura.

Al ser comparados entre sí, los dentífricos conteniendo fitoterápicos mostraron la misma acción antimicrobiana sobre las cepas patrón y sobre las bacterias orales recuperadas de la saliva.

Llevando en consideración la acción del dentífrico control positivo (Sorriso Ação Total ${ }^{\circledast}$ conteniendo triclosan) contra las bacterias orales recuperadas de la saliva y contra las cepas patrón para el cálculo del modelo estadístico en relación con los dentífricos evaluados, fue verificado que solamente las soluciones puras de éstos presentaron capacidad antimicrobiana equivalente a la del dentífrico conteniendo triclosan.

Todos los dentífricos evaluados presentaron acción antimicrobiana excepto el Parodontax ${ }^{\circledast}$ y Phillips $^{\circledast}$ (control negativo).

Basados en lo antes expuesto, fue observado que los agentes fitoterápicos incorporados a los dentífricos poseen acción antimicrobiana sobre las bacterias orales, lo cual sugiere realizar investigaciones sobre el uso indiscriminado de éstos productos y sobre sus posibles consecuencias en la salud bucal. 


\section{REFERENCIAS BIBLIOGRÁFICAS}

1. Silveira E. Ajuda que vem do verde. Seu Guia Prático de Plantas Medicinais 1999; 12: 9-13.

2. Silveira E. Cosméticos caseiros. Seu Guia Prático de Plantas Medicinais 1999; 12: 9-13.

3. Fernandes LMAG, Assunção IV. Dentifrícios. In: Oliveira AGRC, Albuquerque AJ, Rego DM, Silva EM, Souza ECF, Costa ICC, Assunção IV, Domingues JEG, Lima KC, Fasanaro KT, Fernandes LMAG, Oliveira MAF, Alves MSCF, Leite MJVF, Araújo OL, Costa PAP, Alves TPS. Odontologia preventiva e social: textos selecionados. EDUFRN. Natal(RN): 1997.p.179-90.

4. Forever Living. O Que é Aloe Vera? Texto informativo 1997.

5. Forever Living. Propriedades da Aloe Vera Forever Living. Texto informativo 1997.

6. Forever Living. O Conteúdo e as Propriedades do Aloe Vera Gel. Texto informativo 1999.

7. Forever Living. Aloe: Perspectiva Histórica. Texto informativo 1999.

8. Lunguinho MSL. Performance da raspa do Ziziphus joazeiro Mart no processo de higiene oral: um estudo químico-odontológico [dissertation]. Natal(RN): Univ. Fed. do Rio Grande do Norte; 1989.

9. MATOS FJA. Farmácias vivas. Fortaleza (CE): UFC; 1998.

10. Pereira JV. Atividade antimicrobiana do extrato hidroalcóolico da Punica granatum Linn sobre microrganismos formadores da placa bacteriana [dissertation]. João Pessoa(PB): Uni. Fed. da Paraíba; 1998.

11. Teske M, Trentini AMM. Compêndio de fitoterapia. Curitiba(PR): Herbarium; 1994.

12. XAVIER MN. A fitoterapia no combate às infecções bucais. João Pessoa (PB): Idéia; 1995.

13. Velmovitsky I; Lima KC; Magalhães FAC; Uzeda M. Inibição de microrganismos cariogênicos: um estudo in vitro de pastas comercializadas na Brasil. XXI Congresso Brasileiro de Microbiologia; 2001 p.119; Foz do Iguaçu; Brasil.

14. VIEIRA AMGS. Atividade antimicrobiana de antissépticos orais e dentifrícios para bebês: um estudo sobre células sésseis e planctônicas [tese]. Rio de Janeiro(RJ): Univ. Fed. do Rio de Janeiro; 1999.

15. Gebara ECE, Zardetto CGDC, Mayer MPA. Estudo in vitro da ação antimicrobiana de substâncias naturais sobre S. mutans e S. sobrinus. Rev.Odontol. Univ. São Paulo 1996; 10:251456.

\section{CORRESPONDENCIA}

Universidad Federal de Rio Grande del Norte;

Departamento de Odontologia;

Disciplina de Odontologia Preventiva y Social

Enderezar: Avenida Senador Salgado Filho $n^{\circ} 1787$, Bairro Lagoa Nova,

cep: 59056-000, teléfono /fax (84) 215-4133, Natal/RN - Brasil 